Research Article

\title{
Association between Knops blood group polymorphisms and susceptibility to malaria in an endemic area of the Brazilian Amazon
}

\author{
Aparecida Maria Fontes ${ }^{1,2}$, Simone Kashima ${ }^{1,3}$, Ricardo Bonfim-Silva ${ }^{1,2}$, Rochele Azevedo ${ }^{1}$, \\ Kuruvilla Joseph Abraham ${ }^{4}$, Sérgio Roberto Lopes Albuquerque ${ }^{5}$, José Orlando Bordin ${ }^{6}$, \\ Dante Mário Langhi Júnior ${ }^{7}$ and Dimas Tadeu Covas ${ }^{1,2}$ \\ ${ }^{1}$ Hemocentro de Ribeirão Preto, Instituto Nacional de Ciência e Tecnologia em Células Tronco \\ e Terapia Celular, Hospital das Clínicas, Faculdade de Medicina de Ribeirão Preto, \\ Universidade de São Paulo, Ribeirão Preto, SP, Brazil. \\ ${ }^{2}$ Faculdade de Medicina de Ribeirão Preto, Universidade de São Paulo, Ribeirão Preto, SP, Brazil. \\ ${ }^{3}$ Faculdade de Ciências Farmacêuticas de Ribeirão Preto, Universidade de São Paulo, Ribeirão Preto, \\ SP, Brazil. \\ ${ }^{4}$ Department of Animal Science, Iowa State University, Ames, IA, USA. \\ ${ }^{5}$ Hemocentro do Amazonas, Manaus, AM, Brazil. \\ ${ }^{6}$ Universidade Federal de São Paulo, São Paulo, SP, Brazil. \\ ${ }^{7}$ Faculdade de Ciências Médicas, Santa Casa de São Paulo, São Paulo, SP, Brazil.
}

\begin{abstract}
Complement receptor 1 (CR1) gene polymorphisms that are associated with Knops blood group antigens may influence the binding of Plasmodium parasites to erythrocytes, thereby affecting susceptibility to malaria. The aim of this study was to evaluate the genotype and allele and haplotype frequencies of single-nucleotide polymorphisms (SNPs) of Knops blood group antigens and examine their association with susceptibility to malaria in an endemic area of Brazil. One hundred and twenty-six individuals from the Brazilian Amazon were studied. The CR1-genomic fragment was amplified by PCR and six SNPs and haplotypes were identified after DNA sequence analysis. Allele and haplotype frequencies revealed that the $K n^{b}$ allele and $\mathrm{H} 8$ haplotype were possibly associated with susceptibility to Plasmodium falciparum. The odds ratios were reasonably high, suggesting a potentially important association between two Knops blood antigens $\left(K n^{b}\right.$ and $\left.K A M^{*}\right)$ that confer susceptibility to $P$. falciparum in individuals from the Brazilian Amazon.
\end{abstract}

Key words: Brazilian Amazon population, CR1 haplotypes, Knops blood group polymorphism, malaria.

Received: February 4, 2011; Accepted: July 14, 2011.

\section{Introduction}

Malaria is a widespread parasitic disease of humans. Up to 800,000 people die from this disease each year and $>$ $40 \%$ of the world population lives with some risk of contracting malaria (Kappe et al., 2010). Malaria in humans can be caused by four species of Plasmodium, of which Plasmodium falciparum is responsible for most cases of the disease and death across sub-Saharan Africa, while Plasmodium vivax is the most prevalent parasite in other parts of the world where malaria is present (Kappe et al.,

Send correspondence to Aparecida Maria Fontes. Centro Regional de Hemoterapia, Instituto Nacional de Ciência e Tecnologia em Células Tronco e Terapia Celular, Hospital das Clínicas, Faculdade de Medicina de Ribeirão Preto, Universidade de São Paulo, R. Tenente Catão Roxo 2501, 14051-140 Ribeirão Preto, SP, Brazil. E-mail: fontesam @ hemocentro.fmrp.usp.br.
2010). In Brazil, 457,659 cases of malaria were registered in the Amazon region in 2007, which corresponded to an annual parasitic incidence (API) of 19.2 cases/1,000 individuals (Fernandes de Oliveira et al., 2010).

There is a complex host-parasite interaction that involves both of these genomes, as well as environmental factors. No matter how prominent the role of the environment, the primary importance of genetic factors is best demonstrated by the species-specific nature of plasmodial infections. For example, the capacity of a given Plasmodium species to infect one host and not another may reflect genetic differences between the two hosts. However, the complexity of host-parasite interactions is generally so great that the nature of such genetic differences is not easy to analyze (Luzzatto, 1974). 
One of the features of infection by Plasmodium is the process of rosetting, which is characterized by the binding of $P$. falciparum-infected erythrocytes to uninfected erythrocytes to form clusters of cells that contribute to the pathology of P. falciparum malaria by obstructing blood flow in small blood vessels (Rowe et al., 1995, 1997). Complement receptor 1 (CR1) gene polymorphisms are associated with rosetting of Plasmodium-infected erythrocytes. Previous studies demonstrated that CR1 gene polymorphisms may influence the binding of protozoa to erythrocytes or of infected erythrocytes to non-infected cells (Rowe et al., 1997, 2000, Moulds et al., 2000).

The Knops blood system consists of the antithetical pairs of Knops antigens a and b $\left(K n^{a}\right.$ and $\left.K n^{b}\right)$, McCoy a and $\mathrm{b}\left(M c C^{a}\right.$ and $\left.M c C^{b}\right), K A M^{+} / K A M$ and Swain-Langley/Vil (Sll and Sl2), as well as Sl4, Sl5, Yk $k^{a}$ and Sl3. These antigens, which are associated with the CR1 gene, are membrane-bound molecules found in various cell types, including erythrocytes, macrophages, lymphocytes, dendritic cells and renal podocytes (Daniels et al., 2004, 2007; Moulds et al., 2002, 2004).

The domain responsible for the Knops system antigens is associated with the plasma membrane and consists of 30 short consensus repeats (SCRs), each composed of 60 amino acids. The Knops blood system antigens are mapped to the SCR25 domain of the CR1 protein and each of these polymorphic forms results from the substitution of a single amino acid in this region. Thus, the variant antigens $\mathrm{Kn}^{b}$, $M c C^{b}, S l 2, S l 4$ and $K A M^{+}$result from amino acid substitutions V1561M, K1590E, R1601G, S1610T and I1615V, respectively (Daniels et al., 2004, 2007; Moulds et al., 2001, 2002).

We recently demonstrated a new polymorphism in the SCR25 domain of the CR1 protein at $-4646 A>G$ that, together with the five previously described polymorphisms, gives rise to 12 haplotypes (Covas et al., 2007). The frequency of these haplotypes varies considerably among populations of African and non-African descendant. The H3 haplotype is the most frequent haplotype among African-Brazilians and includes the Sl2 and $K A M^{+}$antigens (Covas et al., 2007).

One of the most studied SNP of the Knops blood system is the $-4828 \mathrm{~A}>\mathrm{G}$ polymorphism that produces the $S l 2$ antigen $(\mathrm{R} 1601 \mathrm{G})$, which is associated with reduced rosette formation by $P$. falciparum-infected erythrocytes in vitro when compared to non-infected erythrocytes. These results were obtained with erythrocytes from American subjects of African descendant carrying the Sl2 phenotype. The erythrocytes of these individuals showed lower binding to recombinant COS cells carrying the $P$. falciparum erythrocyte membrane protein 1 (PfEMP1) compared to normal erythrocytes (Sl1) (Rowe et al., 1997). These data were later confirmed in studies with $P$. falciparum isolates (Rowe et al., 2000). These findings led to the hypothesis that the $S l 2$ phenotype may protect against severe forms of malaria because erythrocytes expressing this Knops blood group antigen have a lower propensity to form rosettes.

Based on these considerations, in this study we examined the frequency of $-4646 A>G,-4708 G>A,-4795 A>G$, $-4828 A>G,-4855 T>A$ and $-4870 A>G$ single-nucleotide polymorphisms (SNPs) and the 12 derived haplotypes, as well as their relationship to the susceptibility of infection by different species of malaria parasites in individuals from an endemic area in the Brazilian state of Amazonas.

\section{Material and Methods}

\section{Subjects}

121 Brazilian subjects from an endemic malaria region (Presidente Figueiredo town) in the state of Amazonas answered a questionnaire designed to obtain epidemiological data related to malaria infection and specific infectious agents. Five individuals for whom no age was recorded were excluded from the analysis, resulting in 119 subjects. These individuals were classified into two groups: infected cases $(\mathrm{n}=92)$ if they had any history of infection by Plasmodium species, and controls $(n=27)$ if they had no history of infection. The subjects considered to be infected were classified according to the Plasmodium species involved: $P$. falciparum $(\mathrm{n}=25), P$. vivax $(\mathrm{n}=34)$ and $P$. falciparum plus $P$. vivax $(\mathrm{n}=33)$. The study was approved by the Institutional Ethics Committee from Hemocentro of Amazonas and all individuals gave written informed consent prior to participating in the study. The control subjects were matched to the infected subjects with regard to gender and caboclo ethnicity, but they were significantly older than the cases (33 years old control group and 39 years old infected group, $\mathrm{p}=0.044)$.

\section{Polymerase chain reaction}

Genomic DNA was isolated from $10 \mathrm{~mL}$ peripheral blood samples using Super Quick-Gene DNA isolation kits (Analytical Genetic Testing Center, Denver, CO, USA) according to the manufacturer's instructions. After extraction and solubilization in ultra pure water, the DNA was concentration was adjusted to $100 \mathrm{ng} / \mu \mathrm{L}$ based on photometric analysis. The CR1 gene was amplified by the polymerase chain reaction (PCR) using the following pair of primers: 5'-CCCTCACACCCAGCAAAGTC-3' and 5'-TAAAAA ATAAGCTGTTTTACCATACTC-3' which amplify a 476 bp DNA fragment. The amplification reactions containing $100 \mathrm{ng}$ of DNA, 1.0 U of Taq DNA polymerase (Invitrogen Life Technologies, São Paulo, Brazil), $50 \mathrm{mM}$ $\mathrm{KCl}, 20 \mathrm{mM}$ Tris-HCl, pH 8.3, $1.5 \mathrm{mM} \mathrm{MgCl}_{2}, 0.2 \mathrm{mM}$ of each deoxynucleotide triphosphate (dNTP) and 0.3 pmol of each specific primer were run in a GeneAmp PCR System 9700 (Applied Biosystems, Foster City, CA, USA). The cycle conditions were: 35 cycles at $94{ }^{\circ} \mathrm{C}$ for $40 \mathrm{~s}, 60{ }^{\circ} \mathrm{C}$ for $40 \mathrm{~s}$ and $72{ }^{\circ} \mathrm{C}$ for $40 \mathrm{~s}$, with a final extension at $72{ }^{\circ} \mathrm{C}$ for $10 \mathrm{~min}$. The amplified products were analyzed by electro- 
phoresis in $1 \%$ agarose gels followed by ethidium bromide staining.

\section{DNA sequencing}

Polymorphisms related to the Knops blood system $(C R 1-4708 G>A, C R 1-4795 A>G, C R 1-4828 A>G$, $C R 1-4855 T>A, C R 1-4870 A>G$ and $C R 1-4646 A>G$ ) were investigated by DNA sequencing of the CR1 gene. Sequencing reactions were done using the PCR primers indicated above and the DYEnamic ET dye terminator kit (GE Healthcare UK Ltd., Amersham, UK) according to the manufacturer's instructions. Electrophoresis was done using an automated MegaBace DNA sequencing system 1000 (Amersham Biosciences, Uppsala, Sweden). The electropherograms were analyzed using Sequence Analyzer software version 1 (Amersham Biosciences) and the data were processed using the Phred program (Ewing and Green, 1998; Ewing et al., 1998) that generated files containing information about the base content and quality of each sequence. The sequences were aligned pairwise to the specific genomic regions using the Cross Match program (http://www.phrap.org). Multiple alignments were produced with PolyBayes multiple alignment algorithms (Marth et al., 1999). Single nucleotide polymorphisms (SNPs) were detected in the highly similar regions of multiple anchored alignments using the PolyPhred program (Nickerson et al., 1997).

\section{Haplotype definition}

The 12 haplotypes reported elsewhere (Covas et al., 2007) were analyzed. These haplotypes (Table 1) were deposited in GenBank under accession numbers AY701493 to AY701504.

\section{Statistical analysis}

The agreement of genotype frequencies with HardyWeinberg expectations was tested using the Genepop program, version 4.0.10. The haplotype frequency was estimated using Arlequin, version 3 (Excoffier et al., 2005). The genotype and allele frequencies of infected and control subjects were compared by the Chi-square test for trend and Fisher's exact test, respectively, using GraphPad Instat software, version 5.0. The level of significance was set at $5 \%(\mathrm{p}<0.05)$ for all tests.

A separate series of analyses (based on using logistic regression) was done at loci 4708 and 4646 by including gender and age as covariates to determine the odds ratio (OR) and the p-values for the correlation between genotypic content and infection status. Four such tests were done by comparing the healthy controls with each of the infected groups and with all infected groups combined. The R software was used for the latter analyses. Although the confidence intervals were calculated for all tests they were not always reliable or reproducible because of the low counts in some cells and were therefore not always reported.

\section{Results}

Table 2 shows the genotype frequencies of the infected groups and controls. The $4708 G A$ heterozygous genotype was more frequent in cases infected with $P$. falciparum $(28 \%, \mathrm{p}=0.021)$ compared with controls $(3.7 \%)$, but there was no significant difference in relation to individuals infected with $P$. vivax or both species. There were no significant differences between infected groups and controls for any of the other genotype frequencies.

When the infected group as a whole was analyzed (Table 3 ), the $4708 G A$ heterozygous genotype was again

Table 1 - Haplotyes previously defined by six SNPs in the CR1 gene.

\begin{tabular}{|c|c|c|c|c|c|c|}
\hline \multirow[t]{2}{*}{ Identifier } & \multicolumn{6}{|c|}{ Haplotype } \\
\hline & $\begin{array}{c}\mathrm{N} 1540 \mathrm{~S} \\
4646 A>G\end{array}$ & $\begin{array}{c}K n^{a} / K n^{b} \\
\mathrm{~V} 1561 \mathrm{M} \\
4708 G>A\end{array}$ & $\begin{array}{c}M c C^{a} / M c C^{b} \\
\mathrm{~V} 1590 \mathrm{E} \\
4795 A>G\end{array}$ & $\begin{array}{c}\text { Sl1/Sl2 } \\
\mathrm{R} 1601 \mathrm{G} \\
4828 A>G\end{array}$ & $\begin{array}{c}\text { Sl4/Sl5 } \\
\mathrm{S} 1610 \mathrm{~T} \\
4855 T>A\end{array}$ & $\begin{array}{c}K A M / K A M^{+} \\
\mathrm{I} 1615 \mathrm{~V} \\
4870 A>G\end{array}$ \\
\hline H1 & A & G & A & A & $\mathrm{T}$ & A \\
\hline $\mathrm{H} 2$ & A & G & A & A & $\mathrm{T}$ & G \\
\hline H3 & A & $\mathrm{G}$ & A & G & $\mathrm{T}$ & G \\
\hline H4 & A & G & G & A & $\mathrm{T}$ & G \\
\hline H5 & A & G & G & G & $\mathrm{T}$ & G \\
\hline H6 & $\mathrm{A}$ & G & G & G & $\mathrm{T}$ & A \\
\hline H7 & A & $\mathrm{G}$ & A & G & $\mathrm{T}$ & A \\
\hline H8 & $\mathrm{A}$ & A & A & A & $\mathrm{T}$ & G \\
\hline H9 & G & G & A & A & $\mathrm{T}$ & G \\
\hline $\mathrm{H} 10$ & G & G & A & A & $\mathrm{T}$ & A \\
\hline H11 & A & A & A & A & $\mathrm{T}$ & A \\
\hline H12 & A & G & $\mathrm{A}$ & A & A & $\mathrm{G}$ \\
\hline
\end{tabular}


Table 2 - Genotype frequencies of six SNPs in the CR1 gene in control subjects and three groups of infected subjects (P. falciparum, $P$. vivax and P.falciparum + P. vivax).

\begin{tabular}{|c|c|c|c|c|c|c|c|c|}
\hline & & $\begin{array}{l}\text { Controls } \\
(\mathrm{n}=27)\end{array}$ & $\begin{array}{c}\text { P. falciparum } \\
(\mathrm{n}=25)\end{array}$ & $\mathrm{p}$ & $\begin{array}{l}\text { P. vivax } \\
(\mathrm{n}=34)\end{array}$ & $\mathrm{p}$ & $\begin{aligned} & \text { P. falciparum } \\
+ & P . \operatorname{vivax}(\mathrm{n}=33)\end{aligned}$ & $\mathrm{p}$ \\
\hline CR1-4646 $A>G$ & $\mathrm{~A} / \mathrm{A}$ & $18(66.6 \%)$ & $21(84 \%)$ & & $28(82.3 \%)$ & & 27 (81.8\%) & \\
\hline \multirow[t]{3}{*}{ N1540S } & $\mathrm{A} / \mathrm{G}$ & $7(25 \%)$ & $4(16 \%)$ & & $6(17.7 \%)$ & & $6(18.2 \%)$ & \\
\hline & $\mathrm{G} / \mathrm{G}$ & $2(7.4 \%)$ & $0(0 \%)$ & & $0(0 \%)$ & & $0(0 \%)$ & \\
\hline & & & & - & & - & & - \\
\hline CR1-4708 $G>A$ & $\mathrm{G} / \mathrm{G}$ & $26(93.3 \%)$ & $18(72 \%)$ & & $28(82.3 \%)$ & & $26(78.8 \%)$ & \\
\hline V1561M & $\mathrm{G} / \mathrm{A}$ & $1(3.7 \%)$ & $7(28 \%)$ & & $6(17.7 \%)$ & & $7(21.2 \%)$ & \\
\hline \multirow[t]{2}{*}{$K n^{a / b}$} & $\mathrm{~A} / \mathrm{A}$ & $0(0 \%)$ & $0(0 \%)$ & & $0(0 \%)$ & & $0(0 \%)$ & \\
\hline & & & & 0.0216 & & 0.1207 & & 0.063 \\
\hline CR1-4795 $A>G$ & $\mathrm{~A} / \mathrm{A}$ & $25(92.6 \%)$ & $21(84 \%)$ & & $31(91.2 \%)$ & & $31(93.9 \%)$ & \\
\hline $\mathrm{K} 1590 \mathrm{E}$ & $\mathrm{A} / \mathrm{G}$ & $2(7.4 \%)$ & $4(16 \%)$ & & $2(5.9 \%)$ & & $2(6.1 \%)$ & \\
\hline \multirow[t]{2}{*}{$M c C^{a / b}$} & $\mathrm{G} / \mathrm{G}$ & $0(0 \%)$ & $0(0 \%)$ & & $1(2.9 \%)$ & & $0(0 \%)$ & \\
\hline & & & & - & & - & & - \\
\hline $\mathrm{CR} 1-4828 A>G$ & $\mathrm{~A} / \mathrm{A}$ & $20(74.1 \%)$ & $17(68 \%)$ & & $30(88.2 \%)$ & & $23(69.7 \%)$ & \\
\hline $\mathrm{R} 1601 \mathrm{G}$ & $\mathrm{A} / \mathrm{G}$ & $7(25.9 \%)$ & $8(32 \%)$ & & $3(8.8 \%)$ & & $9(27.3 \%)$ & \\
\hline \multirow[t]{2}{*}{ Sll/Sl2 } & $\mathrm{G} / \mathrm{G}$ & $0(0 \%)$ & $0(0 \%)$ & & $1(3 \%)$ & & $1(3 \%)$ & \\
\hline & & & & 0.630 & & 0.319 & & 0.563 \\
\hline CR1-4855 $T>A$ & $\mathrm{~T} / \mathrm{T}$ & $27(100 \%)$ & $25(100 \%)$ & & $34(100 \%)$ & & $33(100 \%)$ & \\
\hline S1610T & $\mathrm{T} / \mathrm{A}$ & $0(0 \%)$ & $0(0 \%)$ & & $0(0 \%)$ & & $0(0 \%)$ & \\
\hline \multirow[t]{2}{*}{ Sl4/Sl5 } & $\mathrm{A} / \mathrm{A}$ & $0(0 \%)$ & $0(0 \%)$ & & $0(0 \%)$ & & $0(0 \%)$ & \\
\hline & & & & - & & - & & - \\
\hline $\mathrm{CR} 1-4870 A>G$ & $\mathrm{~A} / \mathrm{A}$ & $10(37 \%)$ & $5(20 \%)$ & & $12(35.3 \%)$ & & $12(36.4 \%)$ & \\
\hline I1615V & $\mathrm{A} / \mathrm{G}$ & $11(40.7 \%)$ & $15(60 \%)$ & & $14(41.2 \%)$ & & $12(36.4 \%)$ & \\
\hline \multirow[t]{2}{*}{$K A M / K A M^{+}$} & $\mathrm{G} / \mathrm{G}$ & $6(22.3 \%)$ & $5(20 \%)$ & & $8(23.5 \%)$ & & $9(27.2 \%)$ & \\
\hline & & & & 0.448 & & 0.876 & & 0.776 \\
\hline
\end{tabular}

more frequent in the infected group $(21.7 \%)$ compared to the controls $(3.7 \%, \mathrm{p}=0.0415)$. The genotype frequencies of all polymorphisms agreed with those expected for Hardy-Weinberg equilibrium. The p-values listed in Table 3 are those obtained with Fishers exact test for association between case/control status and the $G G$ or $G A$ genotypes.

The allele frequencies for the antigens of the Knops blood system are shown in Table 4. The frequency of the $K n^{b}$ allele $(-4708 A)$ in patients infected with $P$. falciparum $(14 \%)$ was greater than in the controls $(2 \%, \mathrm{p}=0.027)$. However, there was no significant difference in relation to individuals infected with $P$. vivax or $P$. falciparum $+P$. vivax.

The other SNPs showed no significant differences in the genotypic and allelic frequencies between infected and control groups. This finding suggested a possible dependence among alleles. To evaluate this dependence, we analyzed the haplotype frequencies among the studied groups. Twelve previously reported haplotypes (Covas et al., 2007) were evaluated. Comparison of the infected and control groups revealed the presence of six haplotypes (Table 5), with the $\mathrm{H} 1$ and $\mathrm{H} 2$ haplotypes being the most frequent in all groups. The H8 haplotype was most frequent in individuals infected with P. falciparum (14\%) compared to controls $(2 \%)$. A similar result was obtained when all infected individuals were compared to healthy subjects.

Although the number of $K n^{b}$ alleles and H8 haplotypes in the control group was small, there were nevertheless indications of possible correlations with susceptibility to disease. As a further check on the possible association between the $-4708 G>A$ SNP and susceptibility to disease, we performed logistic regression of case/control status against genotype using age and gender as covariates. An appreciable effect of age on logistic regression was observed, with mild evidence linking the genotype to susceptibility to infection by $P$. falciparum when the controls were tested against individuals infected with $P$. falciparum $(\mathrm{OR}=6.68)$ or against all infected cases $(\mathrm{OR}=6.06)$. In each case, the one sided $\mathrm{p}$-values were $\sim 0.04$. A separate permutation test showed that the mean age of the controls was significantly lower than that of infected individuals $(p=0.044)$. Population stratification would not be expected 
Table 3 - Genotype frequencies of six SNPs in the CR1 gene in control subjects and all Plasmodium-infected groups combined.

\begin{tabular}{|c|c|c|c|c|}
\hline & & $\begin{array}{r}\text { Controls } \\
(\mathrm{n}=27)\end{array}$ & $\begin{array}{c}\text { Infected cases } \\
\quad(\mathrm{n}=92)\end{array}$ & $\mathrm{p}$ \\
\hline$C R 1-4646 A>G$ & $\mathrm{~A} / \mathrm{A}$ & $18(66.7 \%)$ & $76(82.6 \%)$ & \\
\hline \multirow{3}{*}{ N1540S } & $\mathrm{A} / \mathrm{G}$ & $7(25.9 \%)$ & $16(17.4 \%)$ & \\
\hline & $\mathrm{G} / \mathrm{G}$ & $2(7.4 \%)$ & $0(0 \%)$ & \\
\hline & & & & - \\
\hline CR1-4708 $G>A$ & $\mathrm{G} / \mathrm{G}$ & $26(96.3 \%)$ & $72(78.3 \%)$ & \\
\hline V1561M & $\mathrm{G} / \mathrm{A}$ & $1(3.7 \%)$ & $20(21.7 \%)$ & \\
\hline \multirow[t]{2}{*}{$K n^{a / b}$} & $\mathrm{~A} / \mathrm{A}$ & $0(0 \%)$ & $0(0 \%)$ & \\
\hline & & & & 0.0415 \\
\hline CR1-4795 $A>G$ & $\mathrm{~A} / \mathrm{A}$ & $25(92.6 \%)$ & $83(90.2 \%)$ & \\
\hline K1590E & $\mathrm{A} / \mathrm{G}$ & $2(7.4 \%)$ & $8(8.7 \%)$ & \\
\hline \multirow[t]{2}{*}{$M c C^{a / b}$} & $\mathrm{G} / \mathrm{G}$ & $0(0 \%)$ & $1(1.1 \%)$ & \\
\hline & & & & - \\
\hline $\mathrm{CR} 1-4828 A>G$ & $\mathrm{~A} / \mathrm{A}$ & $20(74.1 \%)$ & $70(76.1 \%)$ & \\
\hline $\mathrm{R} 1601 \mathrm{G}$ & $\mathrm{A} / \mathrm{G}$ & $7(25.9 \%)$ & $20(21.7 \%)$ & \\
\hline \multirow[t]{2}{*}{$S l 1 / S l 2$} & $\mathrm{G} / \mathrm{G}$ & $0(0 \%)$ & $2(2.2 \%)$ & \\
\hline & & & & - \\
\hline CR1-4855 $T>A$ & $\mathrm{~T} / \mathrm{T}$ & $27(100 \%)$ & $92(100 \%)$ & \\
\hline $\mathrm{S} 1610 \mathrm{~T}$ & $\mathrm{~T} / \mathrm{A}$ & $0(0 \%)$ & $0(0 \%)$ & \\
\hline \multirow[t]{2}{*}{ Sl4/Sl5 } & $\mathrm{A} / \mathrm{A}$ & $0(0 \%)$ & $0(0 \%)$ & \\
\hline & & & & - \\
\hline $\mathrm{CR} 1-4870 A>G$ & $\mathrm{~A} / \mathrm{A}$ & $10(37.0 \%)$ & $29(31.5 \%)$ & \\
\hline I1615V & $\mathrm{A} / \mathrm{G}$ & $11(40.7 \%)$ & $41(44.5 \%)$ & \\
\hline$K A M / K A M^{+}$ & $\mathrm{G} / \mathrm{G}$ & $6(22.3 \%)$ & $22(24.0 \%)$ & \\
\hline
\end{tabular}

to introduce any substantial additional loss of significance in this analysis since all of the individuals in the study were of the same ethnicity. Furthermore, the environmental risk factors were comparable for infected and healthy individuals.

\section{Discussion}

In this study, we evaluated the frequencies of $-4646 \mathrm{~A}$ $>G,-4708 G>A,-4795 A>G,-4828 A>G,-4855 T>A$ and $-4870 A>G$ SNPs in the CR1 gene, and their association with susceptibility to infection by malaria in individuals from an endemic area in the Brazilian state of Amazonas. There was a significant difference in the frequency of the $C R 1-4708 G>A$ SNP between the infected groups and the controls. The $-4708 G A\left(K n^{a} / K^{b}\right)$ heterozygous genotype was more frequent in cases infected with $P$. falciparum (28\%) compared to the controls $(3.7 \%)$. The $K n^{b}$ mutant allele $(-4708 A)$ also showed a higher incidence in cases infected with $P$. falciparum (14\%) than in uninfected individuals $(2 \%)$. This finding contrasts with a study of 100 Indians infected with $P$. falciparum who had a lower fre- quency of $K n^{b}$ compared to the controls (Gandhi et al., 2009). These divergent findings may reflect ethnic differences among the two populations, i.e., caboclo (in this study) versus Indian.

Haplotype analysis revealed that the $-4708 \mathrm{~A}$ mutant allele $\left(K n^{b}\right)$ had only one haplotype (H8) that is characterized by two Knops alleles as mutants [-4708G>A $\left(\mathrm{Kn}^{b}\right)$ and $\left.-4870 A>G\left(K A M^{+}\right)\right]$. On the other hand, haplotype 11, which consists of the $K n^{b}$ mutant allele by itself, was not found in this population. These findings suggest that the $K n^{b}$ allele may associate with the $K A M^{+}$allele to confer susceptibility to infection by $P$. falciparum. Consequently, parasites that invade erythrocytes through the CR1 receptor may be more successful in individuals that express both the $K n^{b}$ and $K A M^{+}$Knops blood antigens.

There was no significant difference in the frequencies of the $-4795 A>G\left(\mathrm{McC}^{\mathrm{a} / \mathrm{b}}\right)$ and $4828 A>G($ Sl1/Sl2 $)$ SNPs between infected and control groups. Sl2 undergoes positive selection in African populations and it has been hypothesized that $S l 2$ by itself and in association with the $M c C^{b}$ allele probably confers a survival advantage in the populations involved (Moulds et al., 2004; Thathy et al., 2005; Barreiro et al., 2008). In contrast, although several studies have examined the effect of the $S / 2$ and $M c C^{b}$ alleles on susceptibility to malaria the results are conflicting.

A case-control study from Gambia found no significant association between the $S l 2$ or $M c C^{b}$ alleles and protection from severe malaria (Zimmerman et al., 2003; Gandhi et al., 2009). Moreover, two recent studies, one from India (Gandhi et al., 2009) and another from Gambia (Jallow et al., 2009), found no significant effect of the Sl2 SNP on susceptibility to malaria. In contrast, a study in western Kenya found that children with the $S l 2 / S l 2$ genotype had a reduced risk of cerebral malaria $(\mathrm{OR}=0.17$; $95 \%$ CI 0.04 to $0.72 ; \mathrm{p}=0.02$ ) compared to children with Sl1/Sl1 (Thathy et al., 2005).

The discrepancies among these studies may again reflect ethnic differences, variation in CR1 expression levels, study design and divergent pathogenic mechanisms (including the intensity of transmission, levels of immunity and interactions with other malaria-resistant genes) in different areas. Additional studies on caboclo Brazilian populations are warranted in order to clarify the influence of genetic background on susceptibility to malaria.

Few case-control studies of Knops blood group SNPs have been reported and most publications have dealt with studies of population structure. The present report provides a case-control study of CR1 gene SNPs that have not previously been studied in individuals from the state of Amazonas in Brazil.

In conclusion, the results described here suggest that susceptibility to $P$. falciparum infection is associated with $K n^{b}$ allele carrier status and with a combination of this allele and the $\mathrm{KAM}^{+}$allele (H8 haplotype). Repeating this study in a larger sample could confirm these associations. 
Table 4 - Allele frequencies in the Knops blood system in control subjects and in three groups of infected individuals ( $P$. falciparum, $P$. vivax and $P$. falciparum + P. vivax).

\begin{tabular}{|c|c|c|c|c|c|c|c|c|}
\hline & & Controls $(\mathrm{n}=27)$ & $\begin{array}{l}\text { P. falciparum } \\
(\mathrm{n}=25)\end{array}$ & $\mathrm{p}$ & P. $\operatorname{vivax}(\mathrm{n}=34)$ & $\mathrm{p}$ & $\begin{aligned} & \text { P. falciparum } \\
+ & P . \operatorname{vivax}(\mathrm{n}=33)\end{aligned}$ & $\mathrm{p}$ \\
\hline CR1-4646 $A>G$ & A & 0.80 & 0.92 & & 0.91 & & 0.91 & \\
\hline \multirow[t]{2}{*}{ N1540S } & G & 0.20 & 0.08 & & 0.09 & & 0.09 & \\
\hline & & & & 0.096 & & 0.112 & & 0.113 \\
\hline \multirow{3}{*}{$\begin{array}{l}\mathrm{CR} 1-4708 G>A \\
\mathrm{Kn}^{a / b}\end{array}$} & $\mathrm{Kn}^{\mathrm{a}}$ & 0.98 & 0.86 & & 0.91 & & 0.89 & \\
\hline & $\mathrm{Kn}^{\mathrm{b}}$ & 0.02 & 0.14 & & 0.09 & & 0.11 & \\
\hline & & & & 0.027 & & 0.132 & & 0.072 \\
\hline \multirow{3}{*}{$\begin{array}{l}\mathrm{CR} 1-4795 A>G \\
M C C^{a / b}\end{array}$} & $\mathrm{McC}^{\mathrm{a}}$ & 0.96 & 0.92 & & 0.94 & & 0.97 & \\
\hline & $\mathrm{McC}^{\mathrm{b}}$ & 0.04 & 0.08 & & 0.06 & & 0.03 & \\
\hline & & & & 0.424 & & 0.692 & & 1.000 \\
\hline \multirow{3}{*}{$\begin{array}{l}\text { CR1-4828 A > G } \\
\text { Sl1/Sl2 }\end{array}$} & S11 & 0.87 & 0.84 & & 0.93 & & 0.83 & \\
\hline & $\mathrm{S} 12$ & 0.13 & 0.16 & & 0.07 & & 0.17 & \\
\hline & & & & 0.782 & & 0.366 & & 0.617 \\
\hline \multirow{3}{*}{$\begin{array}{l}\text { CR1-4855 } T>A \\
\text { Sl4/Sl5 }\end{array}$} & S14 & 1.00 & 1.00 & & 1.00 & & 1.00 & \\
\hline & S15 & 0.00 & 0.00 & & 0.00 & & 0.00 & \\
\hline & & & & - & & - & & - \\
\hline \multirow{3}{*}{$\begin{array}{l}\mathrm{CR} 1-4870 A>G \\
K A M / K A M^{+}\end{array}$} & $\mathrm{KAM}^{-}$ & 0.57 & 0.50 & & 0.56 & & 0.54 & \\
\hline & $\mathrm{KAM}^{+}$ & 0.43 & 0.50 & & 0.44 & & 0.46 & \\
\hline & & & & 0.555 & & 1.000 & & 0.854 \\
\hline
\end{tabular}

Table 5 - Haplotype frequencies of six SNPs in the CR1 gene in control subjects and in three groups of infected individuals (P. falciparum, $P$. vivax and P. falciparum + P. vivax).

\begin{tabular}{|c|c|c|c|c|c|c|c|c|c|c|c|c|}
\hline Group & H1 & $\mathrm{H} 2$ & $\mathrm{H} 3$ & $\mathrm{H} 4$ & H5 & H6 & $\mathrm{H} 7$ & H8 & H9 & $\mathrm{H} 10$ & H11 & $\mathrm{H} 12$ \\
\hline Controls $(\mathrm{n}=27)$ & 0.37 & 0.28 & 0.9 & - & 0.04 & - & - & 0.02 & - & 0.20 & - & - \\
\hline P. falciparum $(\mathrm{n}=25)$ & 0.42 & 0.20 & 0.08 & - & 0.08 & - & - & 0.14 & - & 0.08 & - & - \\
\hline P. $\operatorname{vivax}(\mathrm{n}=34)$ & 0.47 & 0.28 & 0.01 & - & 0.06 & - & - & 0.09 & - & 0.09 & - & - \\
\hline$P$. falciparum $+P . \operatorname{vivax}(\mathrm{n}=33)$ & 0.45 & 0.18 & 0.14 & _ & 0.03 & - & _- & 0.11 & _ & 0.09 & _- & - \\
\hline
\end{tabular}

Further studies will be needed to establish whether these alleles are risk factors or protective factors, and whether other polymorphisms in the CR1 gene are also involved. Functional studies are also needed to determine the mechanism whereby CR1 receptor mutations contribute to the susceptibility of infection by $P$. falciparum in this population.

\section{Acknowledgments}

We thank Adriana Aparecida Marques for technical assistance, and Evandra Strazza Rodrigues and Danielle Aparecida Rosa de Magalhães for help with data analysis and useful scientific discussions. This work was supported by Fundação de Amparo à Pesquisa do Estado de São Paulo (FAPESP), the National Institute of Science and Tecnology in Stem Cell and Cell Therapy/Fundação Hemocentro de Ribeirão Preto (INCTC/FUNDHERP-HC-FMRP/USP) and Conselho Nacional de Desenvolvimento Científico e Tecnológico (CNPq) for scholarship grant (no
314458/2009-3), Brazil. K.J.A. was supported by a USDA-NIFA grant (no. 2009-35205-05100).

\section{References}

Barreiro LB, Laval G, Quach H, Patin E and Quintana-Murci L (2008) Natural selection has driven population differentiation in modern humans. Nat Genet 40:340-345.

Covas DT, de Oliveira FS, Rodrigues ES, Abe-Sandes K, Silva Jr WA and Fontes AM (2007) Knops blood group haplotypes among distinct Brazilian populations. Transfusion 47:147153.

Daniels GL, Fletcher A, Garratty G, Henry S, Jorgensen J, Judd WJ, Levene C, Lomas-Francis C, Moulds JJ, Moulds JM, et al. (2004) Blood group terminology 2004: From the International Society of Blood Transfusion Committee on Terminology for Red Cell Surface Antigens. Vox Sang 87:304316.

Daniels G, Flegel WA, Fletcher A, Garratty G, Levene C, Lomas-Francis C, Moulds JM, Moulds JJ, Olsson ML, Over- 
beeke MA, et al. (2007) International Society of Blood Transfusion Committee on Terminology for Red Cell Surface Antigens: Cape Town report. Vox Sang 92:250-253.

Ewing B and Green P (1998) Base-calling of automated sequencer traces using Phred. II. Error probabilities. Genome Res 8:186-194.

Ewing B, Hillier L, Wendl MC and Green P (1998) Base-calling of automated sequencer traces using Phred. I. Accuracy assessment. Genome Res 8:175-185.

Excoffier L, Laval G and Schneider S (2005) Arlequin v. 3.0: An integrated software package for population genetics data analysis. Evol Bioinform Online 1:147-150.

Fernandes de Oliveira MR, de Castro Gomes A and Toscano CM (2010) Cost effectiveness of OptiMal(R) rapid diagnostic test for malaria in remote areas of the Amazon Region, Brazil. Malaria J 9:277.

Gandhi M, Singh A, Dev V, Adak T, Dashd AP and Joshi H (2009) Role of CR1 Knops polymorphism in the pathophysiology of malaria: Indian scenario. J Vector Borne Dis 46:288-294.

Jallow M, Teo YY, Small KS, Rockett KA, Deloukas P, Clark TG, Kivinen K, Bojang KA, Conway DJ, Pinder M, et al. (2009) Genome-wide and fine-resolution association analysis of malaria in West Africa. Nat Genet 41:657-665.

Kappe SH, Vaughan AM, Boddey JA and Cowman AF (2010) That was then but this is now: Malaria research in the time of an eradication agenda. Science 328:862-866.

Luzzatto L (1974) Genetic factors in malaria. Bull World Health Org 50:195-202.

Marth GT, Korf I, Yandell MD, Yeh RT, Gu Z, Zakeri H, Stitziel NO, Hillier L, Kwok PY and Gish WR (1999) A general approach to single-nucleotide polymorphism discovery. Nat Genet 23:452-456.

Moulds JM, Kassambara L, Middleton JJ, Baby M, Sagara I, Guindo A, Coulibaly S, Yalcouye D, Diallo DA, Miller L, et al. (2000) Identification of complement receptor one (CR1) polymorphisms in West Africa. Genes Immun 1:325-329.

Moulds JM, Zimmerman PA, Doumbo OK, Kassambara L, Sagara I, Diallo DA, Atkinson JP, Krych-Goldberg M, Hauhart RE, Hourcade DE, et al. (2001) Molecular identification of
Knops blood group polymorphisms found in long homologous region D of complement receptor 1. Blood 97:28792885.

Moulds JM, Zimmerman PA, Doumbo OK, Diallo DA, Atkinson JP, Krych-Goldberg M, Hourcade DE and Moulds JJ (2002) Expansion of the Knops blood group system and subdivision of S1(a). Transfusion 42:251-256.

Moulds JM, Thomas BJ, Doumbo O, Diallo DA, Lyke KE, Plowe CV, Rowe JA and Birmingham DJ (2004) Identification of the Kna/Knb polymorphism and a method for Knops genotyping. Transfusion 44:164-169.

Nickerson DA, Tobe VO and Taylor SL (1997) PolyPhred: Automating the detection and genotyping of single nucleotide substitutions using fluorescence-based resequencing. Nucleic Acids Res 25:2745-2751.

Rowe A, Obeiro J, Newbold CI and Marsh K (1995) Plasmodium falciparum rosetting is associated with malaria severity in Kenya. Infect Immun 63:2323-2326.

Rowe JA, Moulds JM, Newbold CI and Miller LH (1997) $P$. falciparum rosetting mediated by a parasite-variant erythrocyte membrane protein and complement-receptor 1. Nature 388:292-295.

Rowe JA, Rogerson SJ, Raza A, Moulds JM, Kazatchkine MD, Marsh K, Newbold CI, Atkinson JP and Miller LH (2000) Mapping of the region of complement receptor (CR) 1 required for Plasmodium falciparum rosetting and demonstration of the importance of CR1 in rosetting in field isolates. $J$ Immunol 165:6341-6346.

Thathy V, Moulds JM, Guyah B, Otieno W and Stoute JA (2005) Complement receptor 1 polymorphisms associated with resistance to severe malaria in Kenya. Malaria J 4:54.

Zimmerman PA, Fitness J, Moulds JM, McNamara DT, Kasehagen LJ, Rowe JA and Hill AV (2003) CR1 Knops blood group alleles are not associated with severe malaria in the Gambia. Genes Immun 4:368-373.

Associate Editor: Angela M. Vianna-Morgante

License information: This is an open-access article distributed under the terms of the Creative Commons Attribution License, which permits unrestricted use, distribution, and reproduction in any medium, provided the original work is properly cited. 